\title{
PENINGKATAN KEMAMPUAN PENALARAN MATEMATIK SISWA KELAS VIII MELALUI PEMBELAJARAN INDUKTIF
}

\author{
R. Zainal Abidin ${ }^{1}$, Heris Hendriana ${ }^{2}$, Wahyu Hidayat ${ }^{3}$ \\ 1,2,3 IKIP Siliwangi Bandung \\ 1ajay_sesep@yahoo.co.id, ${ }^{2}$ herishen@yahoo.com, ${ }^{3}$ wahyu@ ikipsiliwangi.ac.id
}

\begin{abstract}
This research is motivated by the results of previous studies that show that students' mathematical reasoning abilities are not as expected. One of the lessons learned to improve mathematical reasoning ability is inductive learning. The purpose of this study was to determine the increase in students' mathematical reasoning abilities as a result of inductive learning. This research is a quasi-experimental study that applies two learning namely inductive learning and conventional learning. The population in this study were students in one junior high school in West Bandung Regency. Sampling was done by purposive sampling, and obtained two classes as research samples. The research instrument used was a mathematical reasoning ability test. Based on the results of the analysis it was concluded that increasing mathematical reasoning abilities of students who got inductive learning were better than students who got conventional learning.
\end{abstract}

Keywords: Mathematical Reasoning Ability, inductive learning

\begin{abstract}
Abstrak
Penelitian ini dilatarbelakangi oleh hasil-hasil penelitian terdahulu yang menunjukkan bahwa kemampuan penalaran matematis siswa belum sesuai dengan yang diharapkan. Salah satu pembelajaran untuk meningkatkan kemampuan penalaran matematik adalah pembelajaran induktif. Tujuan penelitian ini adalah untuk mengetahui peningkatan kemampuan penalaran matematis siswa sebagai akibat dari pembelajaran induktif. Penelitian ini adalah kuasi eksperimen yang menerapkan dua pembelajaran yaitu pembelajaran induktif dan pembelajaran konvensional. Populasi dalam penelitian ini adalah siswa di salah satu SMP di Kabupaten Bandung Barat. Pengambilan sampel dilakukan secara purposive sampling, dan diperoleh dua kelas sebagai sampel penelitian. Instrumen penelitian yang digunakan adalah tes kemampuan penalaran matematik. Berdasarkan hasil analisis tersebut diperoleh kesimpulan bahwa peningkatan kemampuan penalaran matematik siswa yang mendapat pembelajaran induktif lebih baik daripada siswa yang mendapat pembelajaran konvensional.
\end{abstract}

Kata Kunci: Kemampuan Penalaran Matematik, pembelajaran induktif

How to cite: Abidin, R. Z., Hendriana, H., Hidayat, W. (2018). Peningkatan Kemampuan Penalaran Matematik Siswa Kelas VIII melalui Pembelajaran Induktif. JPMI - Jurnal Pembelajaran Matematika Inovatif, 1 (4), 459-466.

\section{PENDAHULUAN}

Pendidikan matematika di sekolah ditujukan agar siswa memiliki daya nalar yang baik terutama ketika menyelesaikan masalah dalam mata pelajaran matematika. Wahyudin (Usniati, 2011) menemukan bahwa salah satu kecenderungan yang menyebabkan siswa gagal menguasai 
dengan baik pokokpokok bahasan dalam matematika yaitu siswa kurang memahami danmenggunakan nalar yang baik dalam menyelesaikan soal yang diberikan.

Padahal telah disebutkan oleh Depdiknas (Sumartini, 2015) bahwa kemampuan penalaran menjadi salah satu tujuan dalam pembelajaran matematika di sekolah yaitu melatih cara berpikir dan bernalar dalam menarik kesimpulan, mengembangkan kemampuan memecahkan masalah, serta mengembangkan kemampuan menyampaikan informasi atau mengkomunikasikan ide-ide melalui lisan, tulisan, gambar, grafik, peta, diagram dan sebagainya. Begitu juga dengan pendapat (Rosnawati, 2011) yang mengemukakan bahwa rata-rata persentase yang paling rendah yang dicapai oleh peserta didik Indonesia adalah dalam domain kognitif pada level penalaran yaitu $17 \%$.

Namun, mata pelajaran ini banyak yang tidak disukai oleh siswa karena sifatnya yang abstrak dan butuh kesabaran serta kemampuan menganalisa yang baik untuk menyelesaikan suatu permasalahan. Ruseffendi (Sugianto, 2014) mengemukakan bahwa matematika bagi anak-anak pada umumnya merupakan mata pelajaran yang tidak disenangi, kalau bukan sebagai mata pelajaran yang dibenci.

Padahal kemampuan penalaran menjadi salah satu tujuan dalam pembelajaran matematika di sekolah yaitu melatih cara berpikir dan bernalar dalam menarik kesimpulan, mengembangkan kemampuan memecahkan masalah, serta mengembangkan kemampuan menyampaikan informasi atau mengkomunikasikan ide-ide melalui lisan, tulisan, gambar, grafik, peta, diagram, dan sebagainya. Secara rinci diuraikan dalam KTSP (Depdiknas, 2006), peserta didik harus memiliki kemampuan menggunakan penalaran pada pola dan sifat, melakukan manipulasi matematika dalam membuat generalisasi, menyusun bukti, atau menjelaskan gagasan dan peryataan matematika.

Penalaran merupakan suatu kegiatan atau proses berpikir untuk menarik kesimpulan atau membuat pernyataan baru yang didasarkan pada pernyataan sebelumnya dan kebenarannya telah dibuktikan. (Turmudi, 2008) mengatakan bahwa kemampuan penalaran matematis merupakan suatu kebiasaan otak seperti halnya kebiasaan lain yang harus dikembangkan secara konsisten menggunakan berbagai macam konteks, mengenal penalaran dan pembuktian merupakan aspek-aspek fundamental dalam matematika. Dengan penalaran matematis, siswa dapat mengajukan dugaan kemudian menyusun bukti dan melakukan manipulasi terhadap permasalahan matematika serta menarik kesimpulan dengan benar dan tepat (Alhaddad, 2012; Hermawan \& Hidayat, 2018; Hidayat, 2017; Hidayat \& Prabawanto; 2018; Isnaeni, Fajriyah, Risky, Purwasih, \& Hidayat, 2018; Noto, 2015; Sholihat, Hidayat, \& Rohaeti, 2018; Widada, 2016; Yusdiana \& Hidayat, 2018; Zakiah, Saomi, Syara, Hidayat, \& Hendriana, 2018).

Berkenaan dengan penalaran, National Council of Teacher of Mathematics mengatakan bahwa dalam pelaksanaan pembelajaran matematika, guru harus memperhatikan lima kemampuan matematis yaitu: koneksi (connections), penalaran (reasoning), komunikasi (communications), pemecahan masalah (problem solving), dan representasi (representations). Oleh karena itu, guru memiliki peranan dalam menumbuhkan kemampuan penalaran matematis dalam diri siswa baik dalam bentuk metode pembelajaran yang dipakai, maupun dalam evaluasi berupa pembuatan soal yang mendukung.

Meningkatkan kemampuan penalaran matematik siswa perlu didukung oleh pendekatan pembelajaran yang tepat sehingga tujuan pembelajaran dapat tercapai. (Wahyudin, 2008) mengataka bahwa salah satu aspek penting dari perencanaan bertumpu pada kemampuan guru 
untuk mengantisipasi kebutuhan dan materi-materi atau model-model yang dapat membantu para siswa untuk mencapai tujuan pembelajaran. Didukung pula oleh (Sagala, 2011) bahwa guru harus memiliki metode dalam pembelajaran sebagai strategi yang dapat memudahkan peserta didik untuk menguasai ilmu pengetahuan yang diberikan.

Salah satu pembelajaran yang diduga dapat meningkatkan kemampuan penalaran matematik siswa adalah pembelajaran imduktif. Pembelajaran induktif adalah sebuah pembelajaran yang bersifat langsung tapi sangat efektif untuk membantu siswa mengembangkan keterampilan berpikir tingkat tinggi dan keterampilan berpikir kritis. Model pembelajaran induktif adalah sebuah pembelajaran yang bersifat langsung tapi sangat efektif untuk membantu siswa mengembangkan keterampilan berpikir tingkat tinggi dan keterampilan berpikir kritis.

Pada model pembelajaran induktif guru langsung memberikan presentasi informasi-informasi yang akan memberikan ilustrasi-ilustrasi tentang topik yang akan dipelajari siswa, selanjutnya guru membimbing siswa untuk menemukan pola-pola tertentu dari ilustrasi-ilustrasi yang diberikan. Model pembelajaran induktif dirancang berlandaskan teori konstruktivisme dalam belajar. Model ini membutuhkan guru yang terampil dalam bertanya (questioning) dalam penerapannya. Melalui pertanyaan-pertanyaan inilah guru akan membimbing siswa membangun pemahaman terhadap materi pelajaran dengan cara berpikir dan membangun ide.

Tingkat keefektifan model pembelajaran induktif ini, jadinya sangat tergantung pada keterampilan guru dalam bertanya dan mengarahkan pembelajaran, dimana guru harus menjadi pembimbing yang akan untuk membuat siswa berpikir. Struktur sosial dalam pembelajaran menjadi ciri lingkungan kelas yang sangat dibutuhkan untuk belajar melalui model pembelajaran induktif. Model pembelajaran induktif mensyaratkan sebuah lingkungan belajar yang mana di dalamnya siswa merasa bebas dan terlepas dari resiko takut dan malu saat memberikan pendapat, bertanya, membuat konklusi dan jawaban. Mereka harus bebas dari kritik tajam yang dapat menjatuhkan semangat belajar.

Adapun yang dimaksud dengan berpikir induktif adalah suatu proses dalam berpikir yang berlangsung dari hal yang bersifat khusus menuju hal yang lebih umum. Suatu model pembelajaran yang didasarkan atas cara berpikir induktif yaitu model pembelajaran induktif. "Model pembelajaran induktif menurut Hilda Taba juga dikembangkan atas dasar konsep proses mental siswa dengan memperhatikan proses berpikir siswa untuk menangani informasi dan menyelesaikannya" (Bruce, Joyce dan Meil,Marsha 1972).

Menurut (Warimun, 1997) model pembelajaran induktif memiliki karakteristik, sebagai berikut:

1. Digunakan untuk mengajarkan konsep dengan menggeneralisasi.

2. Efektif untuk memotivasi siswa dalam pembelajaran.

3. Menumbuhkan minat siswa karena partisipasi siswa dalam melakukan observasi sangat mendapat penekanan dan siswa secara maksimal diberi kesempatan untuk aktif.

4. Mengembangkan keterampilan proses siswa dalam belajar.

5. Mengembangkan sikap positif terhadap obyek.

Berdasarkan uraian di atas, penulis menduga bahwa pembelajaran induktif dapat meningkatkan kemampuan penalaran matematik siswa SMP. 


\section{METODE}

Jenis Penelitian ini dilaksanakan melalui dua siklus, dengan subjek penelitian siswa SMP kelas VIII di Kabupaten Bandung Barat. Desain penelitian ini menggunakan pembelajaran induktif dengan tahapan perencanaan, tindakan, pengamatan, serta refleksi. Persiapan yang dilakukan, peneliti mengumpulkan data nilai kondisi awal/kemampuan awal siswa, peneliti bersama guru sejawat melakukan diskusi untuk menentukan kompetensi dasar yang akan diteliti, peneliti bersama guru sejawat menelaah indikator-indikator yang ingin dicapai sesuai standar kompetensi dan kompetensi dasar.

Pengumpulan data dilakukan melalui teknik: 1) observasi dalam bentuk catatan guru dan lembar pengamatan tentang kegiatan siswa dalam proses pembelajaran dan buku tugas/catatan materi pelajaran siswa, 2) dokumentasi berupa foto-foto kegiatan dalam proses pembelajaran, 3) wawancara tertulis, 4) tes tertulis, bentuk uraian berupa soal pretes dan ulangan harian.

Penelitian yang digunakan adalah kuasi eksperimen. Desain penelitiannya menggunakan desain kelompok kontrol non ekuivalen.

O X O (Ruseffendi, 2005)

$\mathrm{O} \mathrm{O}$

Keterangan:

$\mathrm{O}$ : Tes kemampuan penalaran matematik siswa

$\mathrm{X}$ : Pembelajaran Induktif

.....: Pengambilan sampel tidak secara acak

\section{HASIL DAN PEMBAHASAN}

\section{Hasil}

Hasil data yang diperoleh dari pretes, postes, dan N-Gain diolah dengan software SPSS 22 dan microsoft exel 2010 disajikan dalam tabel berikut:

Tabel 1. Statistik Deskriptif Kemampuan Penalaran Matematis

\begin{tabular}{lllllll}
\hline & \multicolumn{3}{l}{ Kelas Eksperimen } & \multicolumn{4}{c}{ Kelas Kontrol } \\
\cline { 2 - 7 } & $\mathrm{N}$ & $\chi-$ & $\mathrm{S}$ & $\mathrm{N}$ & $\chi^{-}$ & $\mathrm{S}$ \\
\hline Pretes & 34 & 50,6 & 14,3 & 34 & 49,9 & 12,7 \\
Postes & 34 & 72,8 & 11,7 & 34 & 65,7 & 15,9 \\
N-gain & 34 & 0,4 & 0,3 & 34 & 0,3 & 0,2 \\
\hline \multicolumn{7}{l}{ Skor Maksimal Ideal $=100$} \\
\hline
\end{tabular}

Berdasarkan tabel di atas, terlihat bahwa ada kenaikan yang signifikan antara kemampuan penalaran matematik siswa setelah mendapat perlakuan. Siswa pada kelas eksperimen memperoleh rataan yang lebih besar dari kelas kontrol. Besarnya kenaikan rataan untuk kelas eksperimen dari pretes ke postes sebesar 22,2\% dari skor ideal, sedangkan kenaikan rataan untuk kelas kontrol dari pretes ke postes sebesar 15,8\% dari skor ideal. Secara sepintas, 
gambaran tersebut menunjukkan bahwa kemampuan penalaran matematik siswa pada kelas eksperimen lebih baik dari kelas kontrol. Selain itu, jika dilihat dari peningkatannya, N-gain kelas eksperimen lebih besar dari kelas kontrol, walaupun keduanya diinterpretasikan dalam kategori sedang.

1. Uji Normalitas

Tabel 2. Hasil Uji Normalitas Skor Pretes, Postes dan N-Gain

\begin{tabular}{lll}
\hline Hasil & Kelas & Sig \\
\hline \multirow{2}{*}{ Pretes } & Eksperimen & 0,002 \\
& Kontrol & 0,008 \\
\multirow{2}{*}{ postes } & Eksperimen & 0,200 \\
& Kontrol & 0,000 \\
N-gain & Eksperimen & 0,000 \\
& Kontrol & 0,566 \\
\hline
\end{tabular}

Dari tabel di atas, terlihat bahwa hasil pretes kelas eksperimen dan kelas kontrol memiliki sig $<0,05$, sehingga untuk keduanya Ho ditolak artinya skor pretes kemampuan penalaran matematik siswa kelas eksperimen dan kelas kontrol tidak berdistribusi normal. Untuk hasil postes kelas eksperimen memiliki sig $>0,05$ sehingga Ho diterima artinya skor postes kemampuan penalaran matematik siswa kelas eksperimen berdistribusi normal, dan kelas kontrol memiliki sig $<0,05$ sehingga Ho ditolak artinya skor postes kemampuan penalaran matematik siswa kelas kontrol tidak berdistribusi normal. Untuk hasil n-gain kelas eksperimen memiliki sig $<0,05$ sehingga Ho ditolak artinya skor n-gain kemampuan penalaran matematik siswa kelas eksperimen tidak berdistribusi normal, dan kelas kontrol memiliki sig $>0,05$ sehingga Ho diterima artinya skor n-gain kemampuan penalaran matematik siswa kelas kontrol berdistribusi normal. Karena ada salah satu kelas yang tidak berdistribusi normal, maka uji selanjutnya untuk pretes, postes dan n-gain menggunakan uji nonparametrik yaitu uji Mann Whitney-U.

2. Uji Kesamaan Rataan Pretes dan Postes Kemampuan Penalaran Matematik

Tabel 3. Hasil Uji Kesamaan Rataan Pretes Kemampuan Penalaran Matematik

\begin{tabular}{cc}
\hline Test Statistics $^{\mathbf{a}}$ & Kelas \\
\hline Mann-Whitney U & 495,000 \\
Wilcoxon W & 1090,000 \\
Z & $-1,029$ \\
Asymp.Sig. (2- &, 304 \\
tailed) & \\
\hline
\end{tabular}

a. Grouping Variable :

Berdasarkan hasil di atas, diperoleh nilai $\operatorname{sig}=0,304$. Karena nilai $\operatorname{sig}>0,05$ maka Ho diterima. Hal ini berarti tidak terdapat perbedaan rataan skor pretes kemampuan penalaran matematik pada kelas eksperimen dan kelas kontrol. 
Tabel 4. Hasil Uji Kesamaan Rataan Postes Kemampuan Penalaran Matematik

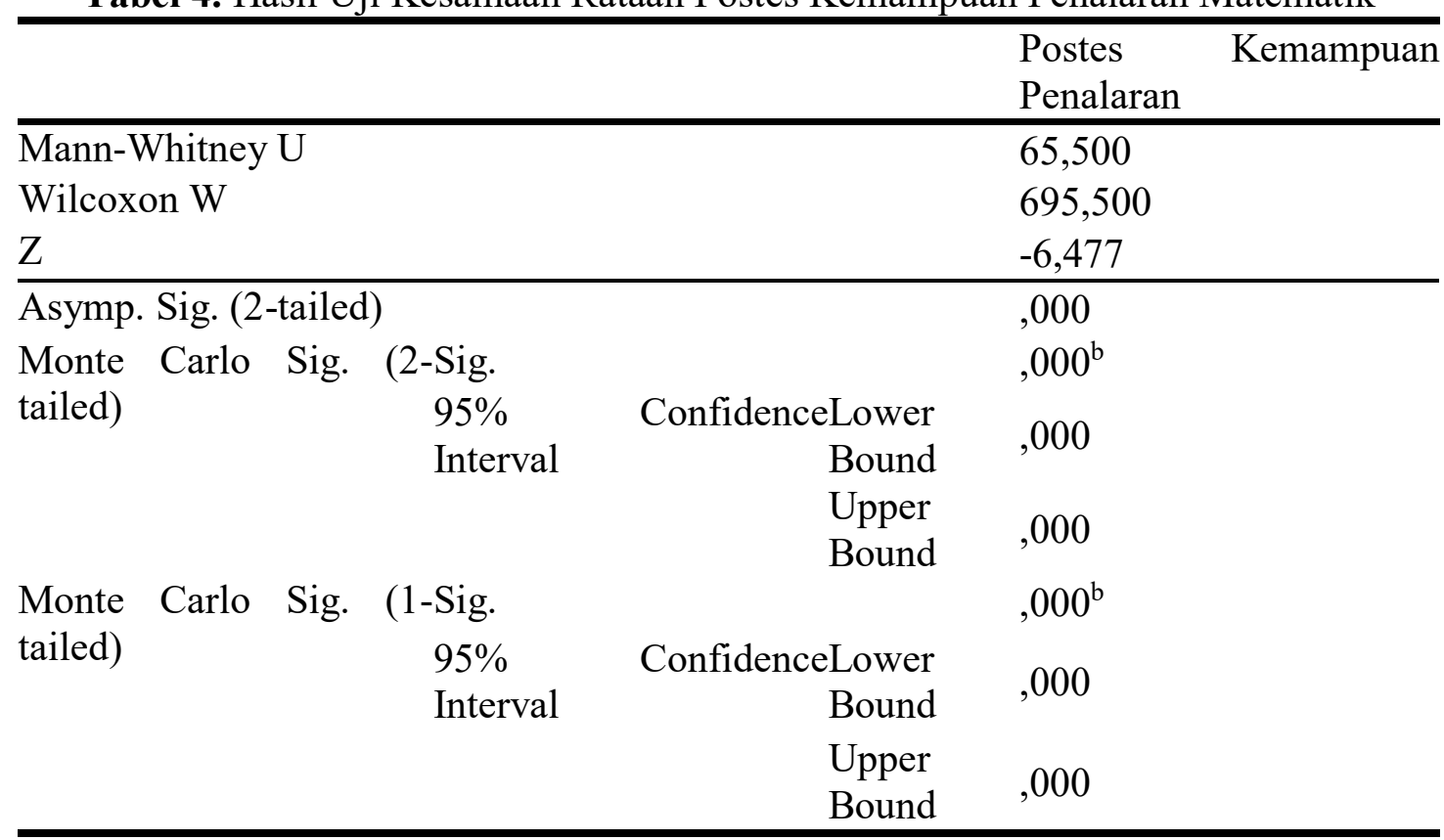

Berdasarkan pada Tabel 4.7 diperoleh nilai signifikasi Monte Carlo sig. (1-tailed) 0,000, nilai ini $<0,05$ maka $\mathrm{H}_{0}$ ditolak, artinya kemampuan penalaran matematik siswa SMP yang pembelajarannya menggunakan pendekatan induktif lebih baik daripada siswa yang menggunakan pembelajaran biasa.

3. Uji Perbedaan Rataan Skor N-gain Kemampuan Penalaran Matematik

Tabel 5. Hasil Uji Perbedaan Rataan Skor N-gain Kemampuan Penalaran Matematik

\begin{tabular}{cc}
\hline Test Statistics $^{\mathbf{a}}$ & Kelas \\
\hline Mann-Whitney U & 401,500 \\
Wilcoxon W & 996,500 \\
Z & $-2,167$ \\
$\begin{array}{l}\text { Asymp.Sig. (2- } \\
\text { tailed) }\end{array}$ &, 030 \\
\hline \multicolumn{2}{c}{ a. Grouping Variable: } \\
$\quad$ Kelombok
\end{tabular}

Berdasarkan tabel di atas, diperoleh nilai sig, $(2$-tailed $)=0,030$ maka sig, $(1$-tailed $)=0,015$. Karena sig.(1-tailed) $<0,05$ artinya Ho ditolak. Hal ini berarti peningkatan kemampuan penalaran matematik siswa yang mendapat pembelajaran induktif lebih baik dari pada siswa yang mendapat pembelajaran konvensional.

\section{Pembahasan}

Dalam Secara umum pembelajaran materi lingkaran di kelas VIII SMPN Satu Atap Rimbakarya Bandung Barat dengan pendekatan induktif berjalan dengan baik, tanpa kendala serius, sekolah memfasilitasi dan siswa termasuk semangat dalam belajar. Adapun beberapa hal menjadi catatan penting yang teramati selama proses pembelajaran akan di analisis berdasarkan variabel yang ada di penelitian ini. Pembahasan hasil penelitian ini didasarkan pada data yang di analisis dari temuan-temuan di lapangan. Banyak faktor yang dicermati dalam penelitian ini, diantaranya peningkatan dan pencapaian yang didapat yaitu kemampuan penalaran matematik dalam pembelajaran lingkaran dengan menggunakan pendekatan induktif. 
Hasil pretes kemampuan penalaran matematik pada kedua kelas sampel setelah dianalisis menunjukan bahwa pretes pada kelas eksperimen yaitu kelas yang menggunakan pendekatan induktif dan pada kelas kontrol yaitu pada kelas dengan menggunakan pembelajaran biasa tidak terdapat perbedaan yang signifikan. Tidak ada perbedaan rata-rata skor pretes dibuktikan dengan uji mann-whitney karena data pada kedua kelas sampel tersebut tidak berdistribusi normal. Sehingga dapat di simpulkan bahwa siswa kedua kelas sampel memiliki kemampuan awal matematik yang sama.

Setelah pelaksanaan pembelajaran dengan pendekatan induktif, maka pada kedua kelas dilakukan postes untuk mengetahui pencapaian kemampuan penalaran matematik siswa pada kedua kelas sampel. Hasil postes kemampuan penalaran matematis pada dua kelas sampel setelah dianalisis menunjukan bahwa postes pada kelas dengan menggunakan pendekatan induktif lebih rendah daripada kelas dengan pembelajaran biasa. Terdapat perbedaan rata-rata skor postes dibuktikan dengan menggunakan uji mann-whitney karena data pada kedua kelas sampel tidak berdistribusi normal. Selanjutnya hasil dari uji perbedaan dua rata-rata skor postes menunjukan perbedaan yang signifikan. Sehingga dapat disimpulkan bahwa kemampuan penalaran matematik siswa yang mendapatkan pembelajaran dengan pendekatan induktif lebih baik daripada yang mendapatkan pembelajaran biasa.

\section{KESIMPULAN}

Dari hasil penelitian ini dapat disimpulkan bahwa :

1. Pencapaian kemampuan penalaran matematik siswa SMP yang pembelajarannya menggunakan pendekatan iduktif lebih baik daripada yang menggunakan pembelajaran biasa.

2. Peningkatan kemampuan penalaran matematik siswa SMP yang pembelajarannya menggunakan pendekatan iduktif lebih baik daripada yang menggunakan pembelajaran biasa.

\section{DAFTAR PUSTAKA}

Alhaddad, I. (2012). Sejauh Mana Guru Menggunakan Metafora Dalam Kepeduliannya untuk meningkatkan Kemampuan Matematika Siswa. Infinity Journal, 1(2), 159-168.

Depdiknas. (2006). Kurikulum Standar Kompetensi Matematika Sekolah Menengah Atas dan Madrasah aliyah. Jakarta.

Hermawan, A. S., \& Hidayat, W. (2018). Meningkatkan Kemampuan Penalaran Matematik Siswa SMP Melalui Pendekatan Penemuan Terbimbing. JPMI (Jurnal Pembelajaran Matematika Inovatif), 1(1), 7-20.

Hidayat, W. (2017). Adversity Quotient dan Penalaran Kreatif Matematis Siswa SMA dalam Pembelajaran Argument Driven Inquiry pada Materi Turunan Fungsi. KALAMATIKA Jurnal Pendidikan Matematika, 2(1), 15-28.

Hidayat, W., \& Prabawanto, S. (2018, January). Improving students' creative mathematical reasoning ability students through adversity quotient and argument driven inquiry learning. In Journal of Physics: Conference Series (Vol. 948, No. 1, p. 012005). IOP Publishing.

Isnaeni, S., Fajriyah, L., Risky, E. S., Purwasih, R., \& Hidayat, W. (2018). Analisis Kemampuan Penalaran Matematis dan Kemandirian Belajar Siswa SMP pada Materi Persamaan Garis Lurus. Journal of Medives, 2(1), 107-116.

Joyce, Bruce dan Marsha, M. (1972). Model of Teaching. New Jersey: Prntice Hall. 
Noto, M. S. (2015). Efektivitas pendekatan metakognisi terhadap penalaran matematis pada matakuliah geometri transformasi. Infinity Journal, 4(1), 22-31.

Rosnawati. (2011). Kemampuan penalaran matematika siswa SMP. In Prosiding seminar nasional.

Ruseffendi, E. . (2005). Dasar- Dasar Penelitian Pendidikan dan Bidang Non-Eksakta Lainnya. Bandung: Tarsito.

Sagala, S. (2011). Konsep dan Makna Pembelajaran. Bandung: Alfabeta.

Sholihat, N. A. N., Hidayat, W., \& Rohaeti, E. E. (2018). PENGHARGAAN DIRI DAN PENALARAN MATEMATIS SISWA MTS. JPMI (Jurnal Pembelajaran Matematika Inovatif), 1(3).

Sugianto. (2014). Perbedaan Penerapan Model Pembelajaran Kooperatif Tipe Jigsaw dan STAD Ditinjau dari Kemampuan Penalaran dan Komunikasi Matematis Siswa SMA. Didaktik Matematika, 1 .

Sumartini, T. S. (2015). Peningkatan Kemampuan Penalaran Matematis Siswa Melalui Pembelajaran Berbasis Masalah. Pendidikan Matematika, 5.

Turmudi. (2008). Landasan Filsafat dan Teori Pembelajaran Matematika Siswa dalam Pelajaran Matematika. Bandung: IKIP.

Usniati. (2011). Meningkatkan Kemampuan Penalaran Matematika Melalui Pendekatan Pemecahan Masalah. UIN Syarif Hidayatullah.

Wahyudin. (2008). Pembelajaran dan Model-Model Pembelajaran. Bandung: IKIP.

Warimun. (1997). Efektivitas Model Pembelajaran Induktif dalam Meningkatkan Prestasi Belajar, Motivasi Brespestasi, dan Sikap Siswa terhadap Perlajaran Fisika. UPI.

Widada, W. (2016). Profile of Cognitive Structure of Students in Understanding the Concept of Real Analysis. Infinity Journal, 5(2), 83-98.

Yusdiana, B. I., \& Hidayat, W. (2018). Analisis Kemampuan Penalaran Matematis Siswa Sma Pada Materi Limit Fungsi. JPMI (Jurnal Pembelajaran Matematika Inovatif), 1(3).

Zakiah, L., Saomi, A. S. N., Syara, R., Hidayat, W., \& Hendriana, H. (2018). The Efficiency Of Using Education Videos On The Linear Program Material As Observed In Vocational High School Students'mathematical Communication Ability. Journal Of Educational Experts (JEE), 1(1), 11-18. 